\title{
Sex, Lies, and the Hillblom Estate: A Decision Analysis
}

\author{
Steven A. Lippman and Kevin F. McCardle* \\ Anderson Graduate School of Management \\ University of California, Los Angeles
}

January 9, 2004

\begin{abstract}
We present three approaches to evaluating a publicly detailed, high-stakes, highrisk decision made by an heir-claimant to the estate of Larry Hillblom. The first two approaches are standard: a decision tree focusing on risk aversion and a multiperiod consumption model that highlights the effects of foregone consumption. We believe the third approach is novel: we embed several Nash bargaining games into the decision tree developed in the first approach. The three approaches yield three different valuations, an indication of the inherent difficulty in modeling real world decisions.
\end{abstract}

*Direct correspondence to either of the authors. Address: The Anderson School, UCLA, Los Angeles, CA 90095-1481, email: slippman@anderson.ucla.edu, kmccardl@anderson.ucla.edu. 


\section{Introduction}

Suppose you have been hired as a decision-analytic consultant by a client whose only asset is a lottery ticket. The lottery pays $\$ 0$ with probability $25 / 55, \$ 27.5$ million with probability $29 / 55$, and $\$ 337.5$ million with probability $1 / 55$. (Expected value $=\$ 20.64$ million.) The lottery will be resolved and paid in five years. (Discounted [at 10\%] expected value $=\$ 12.81$ million.) Your client has just received a firm purchase offer for his ticket of $\$ 12.4$ million in cash to be paid immediately. Surely it would be a fool's errand to find a decision analyst who would advise against selling the ticket (did we mention that the client has no job, no prospect for employment, and no other income?). But if you can find such an analyst, he could join the legal team of Junior Larry Hillbroom, for that is, in essence, the offer from the estate of Larry Hillblom, founder and principal of DHL, that they advised Junior to reject. ${ }^{1}$

We first became aware of the story we are about to tell early in the spring of 1996 . The model we present below was developed early in 1997. While much has happened to the case in the intervening years - suits and counter suits, alleged nefarious behavior by the trustees for the estate and their attorneys, DNA evidence stolen by one party, mislaid and destroyed by the other, stories of a pedophile with a penchant for virgin barmaids, additional claimants coming and going - we will stick to the model, including all probabilities and dollar figures, as we first developed it in early 1997; we fill in the sordid details and surprising outcomes later.

The simplified facts of the case are as follows. Larry Hillblom died in 1994, leaving a fortune worth an estimated $\$ 750$ million before taxes. His will, executed in 1982, left the bulk of his estate in a Trust, the primary beneficiaries of which were the medical schools of the University of California. He never married and had no legitimate children. His will did not include a clause disinheriting any illegitimate children. One such alleged illegitimate child, Junior Larry Hillbroom, born in 1984 (after the will was executed, thereby making him a "pretermitted" child), filed suit claiming a share of the estate. With $\$ 750$ million at stake, it is not surprising that Junior Larry, a budding spear fisherman and wanna-be professional baseball player, all of twelve years old, faced some daunting obstacles to his dreamed-of

\footnotetext{
${ }^{1 ‘ H i l l b r o o m ' ~ i s ~ t h e ~ w a y ~ J u n i o r ' s ~ m o t h e r, ~ K a e l a n i ~ K i n n e y, ~ s p e l l e d ~ h i s ~ n a m e ~ o n ~ h i s ~ b i r t h ~ c e r t i f i c a t e ; ~ a p p a r-~}$ ently her attempt to spell 'Hillblom'.
} 
riches. There was a bill pending in the local legislature that would, in effect, disinherit him; if that bill failed, he had to gain access to sufficient DNA evidence to establish his claim; the evidence must convince a court to grant his claim; and the share of the estate awarded to him, if the court recognized his claim, was at the discretion of the court (it could be the entire estate, though other alleged illegitimate heirs had already surfaced). In early 1996, the trustees of the Hillblom estate, denying all the way to the courthouse that Junior was Larry Hillblom's son, nonetheless offered Junior Larry a deal to relinquish his claim: \$5 million immediately, $\$ 50,000$ a month for life, and an additional $\$ 500,000$ every five years. (The details of the offer were reported in a "Dateline NBC" segment appearing November 8, 1996, including interviews with attorneys for both the estate and for Junior Larry.) Assuming Junior lived another 65 years, the offer had an undiscounted value of over $\$ 50$ million (one of the figures reported in the press), and, if discounted at 10\%, a net present value of about $\$ 12.4$ million (the figure we use as the settlement offer). Alternatively, if we assume a $10 \%$ discount rate, a $6 \%$ annual growth of principal, and level consumption over a 65 year span, the settlement offer generates $\$ 972,600$ per year. Upon advice of legal counsel, Junior Larry rejected this deal, choosing instead to pursue years of litigation and struggle against the wealthy and powerful estate of his claimed father, a man who had repeatedly and publicly stated that he had no children. What were his lawyers thinking?

We found the decision made on behalf of the then 12 year old Junior Larry intriguing and extraordinarily perplexing. Assuming he was acting rationally, what does his decision imply about his beliefs and preferences? How would a decision analyst go about modeling this decision? In the following sections we present three approaches: a decision tree, focusing on risk aversion; a multiperiod consumption model, focusing on the effects of delayed consumption; and an approach we believe to be new, in which we embed several Nash bargaining games in the decision tree. The first two approaches model only Junior Larry's decision. Under very general conditions and for reasonable choices of the parameters, the alternative chosen by Junior Larry is shown to be exceedingly suboptimal. The third approach integrates the decision making on the part of the estate. In this approach, the initial settlement offer also dominates the proposed embedded risk-averse Nash bargaining solution.

There are at least two standard approaches for modeling multi-person decisions with conflicting objectives. The decision-analytic approach takes a particular point of view (the 
protagonist's) and uses a probabilistic model of the opponent's actions. We begin with this approach. Alternatively, the game-theoretic approach models the joint decision as a noncooperative game and applies different notions of equilibria. We propose a third, and we believe novel, approach in the section on embedded Nash bargaining. In contrast to the non-cooperative game-theoretic approach, which requires a rich description of moves and counter-moves, the Nash-bargaining approach requires only the specification of the feasible allocations and disagreement payoffs at each decision node. In contrast to the decisionanalytic approach, which maximizes the protagonist's utility accounting for the opponent's actions through a probability distribution, the Nash-bargaining approach explicitly accounts for the utility of the opponent as well as that of the protagonist. As opposed to weaker cooperative and non-cooperative game-theoretic solutions (for example, assuming only Pareto optimality), the Nash-bargaining approach selects a unique outcome. It results in the two parties efficiently splitting the maximal surplus: each receives half of the surplus. Variations of the Nash-bargaining approach which account for the power of the players are capable of producing each point on the efficient frontier as the outcome. Because of their differing initial endowments, we assign the two parties (Junior and the estate) different utility functions. On the other hand, we find no reason to endow one of them with more bargaining power than the other: both Junior Larry and the estate have a team of high-powered attorneys with easy access to both the Superior Court of CNMI and the court of public opinion.

This paper makes several contributions. First, we tell the titillating tale of the litigation of heir-claimant Junior Larry versus the Hillblom estate in a manner amenable to analysis, pulling together details of the history from a variety of sources. Second, we perform three analyses. Third, and most significantly, we use the tale and its analysis to introduce a new decision tool: embedded Nash bargaining. We propose the embedded Nash-bargaining approach not as a substitute for a standard decision analysis, but rather as a complement to it: embedded Nash bargaining provides a sensitivity analysis that (at least partially) accounts for the decision making of the opponent. 


\section{A Simple Decision Tree}

\subsection{Building the Risk Neutral Tree}

Junior Larry faces an immediate decision to settle for $\$ 12.4$ million or continue his suit. As noted earlier, $\$ 12.4$ million is the NPV of an offer of $\$ 5$ million immediately, $\$ 50,000$ a month, and \$500,000 every five years when discounted using a 10\% interest rate. (Other news reports listed the settlement offer at $\$ 17$ to $\$ 50$ million.) It is possible that rejecting the estate's offer is a ploy for further negotiation: later we return to the idea of negotiation, but for now, we consider the estate's position as a take-it-or-leave-it offer. None of the contemporary news reports described continuing negotiations; they all described continuing litigation. $^{2}$

Our first step is to draw a simple decision tree representation of the uncertainties and decisions Junior Larry faced (see Figure 1). As we describe and fill in this tree, we will provide details of background information, describe the alternatives and events we chose to ignore, and explain the thinking behind our estimates.

If Junior Larry rejects the offer, he pursues the suit. While a decision by Junior to reject the offer would invariably involve a long delay until a resolution of his suit, in this section we do not model the temporal aspects of this alternative. That is, to keep the analysis simple and focused on risk preferences, we do not discount Junior's uncertain payoffs. His legal position is based on standard laws regarding pretermitted children. Larry Hillblom had set up residence in Saipan, the largest island of the Commonwealth of Northern Mariana Islands (CNMI), a chain of small islands in the south Pacific which is a Commonwealth of the United States (the approximately 70,000 CNMI residents hold non-voting U.S. citizenship). CNMI has its own legal code, patterned after U.S. federal laws; appeals from CNMI go directly to a federal court under the jurisdiction of the Federal Court of Appeals for the Ninth Circuit Court. Junior Larry is a native of CNMI, and Larry Hillblom, in order to escape payment of

\footnotetext{
${ }^{2}$ For example, shortly after Junior Larry rejected the settlement offer and the legal wrangling began, Joseph Waechter, onetime president of DHL and executor of the estate, was quoted in the Wall Street Journal (Waldman, 1996) as saying of the alleged heirs, "Anyway you slice it, they're farther from the money now than they've ever been."
} 
U.S. income taxes, established residency in CNMI: the suit against the estate will be heard there. On the issue of pretermitted children, Section 2702 of the Probate Code of CNMI states:

(a) Except as provided in subsection (b), if a testator fails to provide in his (or her) will for any of his (or her) children born or adopted after the execution of the will, the omitted after-born or after-adopted child receives a share in the estate as follows:

(1) If the testator had no child living when he (or she) executed the will, an omitted after-born or after-adopted child receives a share in the estate equal in value to that which the child would have received had the testator died intestate

(B) Neither subsection (a)(1) ... applies if:

(1) it appears from the will that the omission was intentional ...

Continuing with the suit, however, Junior must await the outcome of what has come to be called the Hillblom Law (Public Law 10-10). This law was written under serious financial pressure from the attorneys for the Hillblom estate. If the Hillblom Law passes the CNMI legislature and is signed by the Governor, and if it survives constitutional challenges, it will retroactively invalidate the claims of any illegitimate heirs not specifically mentioned in a will, thereby invalidating Junior Larry's claim. The specific relevant sections of proposed Public Law 10-10 are

(e) The provisions of Section 2702 shall not apply to pretermitted children who have failed to establish paternity by an adjudication prior to the death of the father...

(f) the provisions of this section shall apply to both paternity and heirship actions heretofore or hereafter made, and shall govern in all proceedings in which a final judgment, not subject to further appeal, has not been entered prior to the effective date of this Act.

Section (e) applies because Junior did not move to establish paternity until after Larry Hillblom's death, and (f) applies because a final judgment in the case does not exist and 
is not feasible prior to the law taking effect. In our analysis, we assume that if this law is signed and upheld, Junior Larry would still receive a "small", \$5 million, settlement from the estate. (Our use of this $\$ 5$ million figure represents extreme generosity on the part of the estate. More importantly, it enhances the value of the "pursue litigation" alternative. We use the same $\$ 5$ million amount in two of the other states of the world in which Junior Larry loses the lawsuit.) We assign probability 0.6 to the law passing the legislature and being signed by the Governor, and probability 0.3 to the constitutionality of such a law being upheld on challenge. It may be worth noting that Larry Hillblom was an attorney, a graduate of U.C. Berkeley's Boalt Hall, and had occasionally offered advice to the Supreme Court of the CNMI. He was a big fish in a small pond, well known to all of the other big fish. The trustees of the estate sought to make it clear to those big fish what they thought Larry Hillblom would have wanted. They sent a letter to the speaker of the CNMI House of Representatives offering millions of dollars to CNMI charitable causes, contingent on the passage of Public Law 10-10.

If the law does not survive (either it is not signed, or is rejected on appeal), Junior Larry needs sufficient DNA evidence to establish his claim. Larry Hillblom's body was lost at sea when the small plane that he was piloting disappeared in a storm. While parts of the plane and the bodies of the copilot and passenger were found, Larry Hillblom's body was never found. A search of his home turned up no DNA evidence: no hair in the drains, no toothbrush, no unlaundered clothes or linens. Twelve gallons of muriatic acid had been delivered to his house shortly after his death; by the time Junior Larry's attorneys got there, the house was antiseptically clean. Fortunately for Junior, Larry Hillblom had survived an earlier 1993 plane crash in which he was also the pilot. A mole removed during facial reconstructive surgery after that crash is held by the medical center where the surgery took place. This mole may contain enough DNA to establish paternity, assuming Junior Larry can gain access to it. Unfortunately for Junior, the mole is in the possession of the medical center of the University of California, San Francisco - one of the primary beneficiaries of the estate under the contested will. Alternatively, Larry Hillblom's mother or brothers might be persuaded, bribed, or ordered by a court to donate a DNA sample. We assume that without sufficient DNA evidence, the case can not go forward, and Junior Larry receives only the "small" $\$ 5$ million settlement discussed above. We assign probability 0.8 that Junior Larry 
gains access to DNA from Larry Hillblom's mole or from an immediate blood relative.

If there is sufficient DNA to establish a match, the next uncertainty is whether or not there is a match. If there is no match, Junior Larry will get nothing. From Junior Larry's perspective, the probability of a match may be as high as .9999 (or as low as 0.0001). Without casting aspersions on his mother, we assign probability 0.70 to there being a match between the DNA of Larry Hillblom and that of Junior Larry. (This statement is imprecise - DNA evidence generates likelihood of a match: items with low likelihoods are discarded, items with high likelihoods are said to match.) We assume that if there is a verifiable match, the estate will make a new, more generous settlement offer of $\$ 40$ million.

If there is a match and Junior Larry rejects the new settlement offer, it is then up to a court to determine what share, if any, of the estate that Junior Larry will receive. The federal government gets its $55 \%$ share first via the estate tax. When Junior Larry shows up at the judge's chambers to collect his share of the estate, he might find himself surrounded by a small crowd of other children, some sharing his countenance, each also seeking a portion of the all-too-attractive estate. Larry Hillblom traveled extensively throughout the south Pacific, and there are numerous reports that he enjoyed unprotected sex with very young prostitutes. As a result, there is an army of lawyers combing the bars of Southeast Asia for other potential heirs, wielding posters of a smiling Larry Hillblom and the large caption: "Did you have sex with this man? If so, call 1-800-555-xxxx." While Junior Larry's case may be strong - Larry Hillblom reportedly had provided for his care - it is not likely his is the only one. To account for potential additional heir-claimants and other as yet unforeseen contingencies, we allow Junior Larry 0, 5\%, 10\%, 20\%, and 100\% shares of the after-tax estate with probabilities $0.20,0.20,0.40,0.16$, and 0.04 , respectively.

Although the size of the estate is not known with certainty to Junior Larry, in this section we treat it as fixed at $\$ 750$ million, in essence equilibrating the potential growth of the estate with its potential dissipation. There is some uncertainty regarding the actual size of the estate, with the lawyer for Junior Larry claiming that the trustees were hiding assets. One of the attorneys also expressed concern that rather than growing, the estate would shrink over time as portions of it were used to fight off the claims of Junior Larry and other potential heirs. Furthermore, most of the estate is tied up in the privately held DHL 
Worldwide, so it would be inappropriate to impute a growth rate similar to the stock market as a whole. We choose to ignore all of these uncertainties: while the true value of the estate might be as large as $\$ 1$ billion, and while it may shrink by half over time, the effects of these changes do not change the basic analysis of this section.

Solving the decision tree in Figure 1, ignoring the temporal aspects (i.e., without discounting), and assuming that Junior Larry is risk neutral, yields as the optimal alternative pursuit of the suit with an expected value of just over $\$ 20.63$ million. Of course, all of the probabilities and values in the tree are merely our 1997 estimates of the true values. A sensitivity analysis of the decision is in order.

The probability of a DNA match is the one uncertainty in our tree about which both the estate and Junior Larry may have better information. As noted earlier, from Junior Larry's view this probability can be as high as 1. Prior to gaining access to Larry Hillblom's mole containing his DNA, a press report asserts that the attorney for Junior Larry came into possession of DNA belonging to Larry Hillblom's mother (surreptitiously and illegally obtained from a cotton swab while she was undergoing a dental exam). Given that Junior Larry has rejected the estate's $\$ 12.4$ million offer, we might infer that he assigns a much higher probability to the DNA match than the 0.7 of our model. Changing the probability of a DNA match (given that enough DNA evidence can be obtained) to 1.0 and re-solving the tree increases the expected value of the "pursue suit" branch to $\$ 27.96$ million. Again, the optimal decision for a risk-neutral decision maker is to reject the initial offer and pursue the claim against the estate.

\subsection{Including Risk Aversion}

Returning to the decision tree with probabilities as given in Figure 1, it is a simple matter to include risk aversion in the form of exponential utility:

$$
u(x)=1-e^{-x / R}
$$

where $R$ is the risk tolerance. Exponential utility is particularly tractable: rather than rolling back expected values in the decision tree, we roll back expected utilities. All we need to do is estimate $R$ for Junior Larry. The usual approach (see, e.g., Clemen and Reilly, 2000, 
pp. 543-545) is to ask the decision maker which value of $y$ makes him indifferent between a 50-50 gamble with payoffs $\$ y$ and $\$-y / 2$ and a gamble that pays $\$ 0$ for sure. If exponential utility approximately captures Junior Larry's attitude to risk, then the value $y$ that makes him indifferent is approximately equal to his risk tolerance $R$. Without direct questioning, we are left to hypothesize the value of $R$.

Recognizing the exceedingly speculative nature of a hypothetical gamble involving large sums of money, we estimate our own values of $R$ to be less than $\$ 200,000$, perhaps considerably less. With a risk tolerance of $\$ 200,000$, the certainty equivalent of the initial "reject offer" alternative is $\$ 325,113$. That is, either of the authors of this paper would accept an immediate certain payment of any amount over $\$ 326,000$ (and eagerly accept $\$ 12.4$ million!) rather than pursuing the claim against the estate with uncertainties as depicted in Figure 1.

It is reasonable to assume that the lower his initial wealth, the lower an individual's risk tolerance. (This statement is at odds with the use of exponential utility, which is wealth independent.) We are unaware of any empirical studies of risk tolerances, but there is some anecdotal evidence in Howard (1988). He suggests that firms exhibit risk tolerances on the order of one-sixth of equity or $125 \%$ of net yearly income. Howard's evidence is consonant with lower risk tolerances being associated with lower wealth, where equity or net income are proxies for wealth. Of course, Junior Larry is not a firm; in 1996 he is a 12 year old child tethered to a team of lawyers.

According to contemporary news accounts, in 1996 Junior Larry lives a marginal existence with his grandparents on Saipan. His mother, who was 16 when he was born, continues to work as a barmaid. There are no signs of wealth: his standard of living is quite low. Consequently, we impute to Junior Larry a risk tolerance considerably below ours, say a risk tolerance of $\$ 1000$ as an upper bound. If he has a risk tolerance of $\$ 1000$, then the certainty equivalent of continuing the lawsuit is only $\$ 1625$. For any reasonably imputed value of his risk tolerance based on wealth or living conditions, the settlement offer dominates the certainty equivalent of "pursue suit" by several orders of magnitude.

Rather than imputing a risk tolerance to Junior Larry based on his wealth, we solve for the risk tolerance that makes the certainty equivalent of "pursue suit" equal to $\$ 12.4$ million, the amount he has already rejected. This process yields a lower bound for Junior Larry's risk 
tolerance based on his observed behavior (assuming our model is a reasonable approximation of the real situation). Using our model as captured in Figure 1, the implied lower bound for Junior Larry's risk tolerance is $\$ 18.75$ million. A few comparisons highlight the absurdity of this number. Using Howard's rules of thumb (risk tolerance equal to one-sixth of wealth or one-and-a-quarter times income), a risk tolerance equal to $\$ 18.75$ million is consistent with wealth of about $\$ 112.5$ million or annual income of $\$ 15$ million. Wealth of $\$ 112.5$ million does not earn one a spot on the 1996 Forbes list of 400 wealthiest Americans, where you need to have at least $\$ 520$ million to tie for last place. On the other hand, on the 1998 Forbes list of top paid U.S. CEOs, an income of $\$ 15$ million puts one in position 41: Louis Gerstner, CEO of IBM, is in spot 41 with an income of $\$ 14.902$ million. It is worth noting that Bill Gates, CEO of Microsoft appears on this list in position 749 with an income of $\$ 591,000$. To complete the list comparisons: an income of $\$ 15$ million finds you at number 56 on the 1999 list of the 100 top-paid celebrities, tied with Dennis Rodman and Wayne Gretsky. This is heady company for a dirt-poor adolescent living in CNMI, without access to Forbes or People magazines.

If Junior could somehow raise his current wealth, he might be able to increase his risk tolerance. Raising his risk tolerance might be in his attorney's interest. The legal concept of "champerty", however, renders it illegal for Junior Larry's attorney to pay him or loan him money (which, in essence, raises his wealth) while the case works its way through the legal system. It is, however, legal for Junior Larry to borrow from some other source, using the potential settlement as collateral.

A potential explanation for Junior's behavior may be sought in the work of Hsee and Weber, who study cross-cultural risk perceptions and risk attitudes between American and Asian students (among others). In the first study, Hsee and Weber (1999) find that Chinese students are less risk averse than American students for financial gambles. They hypothesize that this may be due to a "cushioning" effect: members of Asian cultures expect to be taken care of in case of financial failure either by an extended family or by society, thereby reducing the perceived riskiness of downside outcomes. In a follow-up study, Weber and Hsee (1998) show that the differences in risk attitudes noted above (as measured by a willingness to pay for risky gambles) "was predictable almost entirely by differences in the way respondents from these cultures perceived the risk of these options. Thus, Chinese respondents were 
closest to risk neutrality in their pricing of the financial options and judged the risk of these options to be the lowest, but were not significantly more perceived-risk averse." (1998, p. 1215) Extrapolating from the behavior of the Chinese college students in Weber and Hsee's studies to a 12-year-old resident of Saipan, it may be that Junior Larry perceived the risks to be lower than they were, i.e., he judged $\mathrm{P}$ (success) higher than we do. For example, as in the previous section, we can change the probability of a DNA match to 1.0 and recompute the tree, this time using exponential utility. The implied lower bound on risk tolerance with $\mathrm{P}(\mathrm{DNA}$ match $)=1$ is about $\$ 7$ million, a figure no less absurd than a risk tolerance of $\$ 18.75$ million for Junior Larry.

Employing the model developed in Figure 1 and applying exponential utility to account for risk aversion reveals that, for any reasonable values of risk tolerance, Junior chose the suboptimal alternative. See Table 1 for a summary. Furthermore, allowing for the most optimistic extension of the overconfidence suggested by Hsee and Weber continues to reveal the folly of Junior's decision.

\section{Utility for Consumption}

The model of utility presented in the previous section accounts for risk aversion but does not account for consumption preference. We now consider the effects of delayed consumption on the value of the two primary alternatives: accept the $\$ 12.4$ million settlement offer or pursue litigation. Suppose that Junior Larry's preference for a cash flow $x=\left(x_{1}, x_{2}, \ldots, x_{n}\right)$, where $x_{i}$ is the amount consumed in year $i$, is determined by a multi-period utility function

$$
U(x)=\sum_{i=1}^{n} \delta^{i-1} u_{i}\left(x_{i}\right) .
$$

Here $u_{i}\left(x_{i}\right)$ is the instantaneous utility of consumption in year $i$. For specificity in the following calculations, we set $\delta=1 /(1.1)$, i.e., a $10 \%$ consumption discount rate.

Rather than risk aversion, our focus in this section is on the decreasing marginal value of additional consumption and the irrevocable loss that occurs when consumption is delayed. ${ }^{3}$

\footnotetext{
${ }^{3}$ This is similar to the distinction highlighted by Dyer and Sarin (1982). The previous section focuses on risk attitudes, the current section on consumption preferences - what Dyer and Sarin call strength of preference.
} 
We employ the description of the problem as given in Figure 1 in order to effect a comparison. As described earlier, the settlement offer is for an immediate payment of $\$ 5$ million, $\$ 50,000$ a month for life, and a $\$ 500,000$ supplement every five years. To avoid the complex maximization, consumption, and investment problem that would ensue otherwise (see, for example, Miller 1974, Abrams and Karmarkar 1979, or Smith 1998), we use a 65 year residual life span (so Junior will have zero wealth in year 66 when he is 77 years old) and assume level consumption from year to year. Any amounts not consumed are invested and earn 6\% interest. ${ }^{4}$ With these assumptions, if he accepts the settlement offer, he consumes $\$ 972,600$ per year for 65 years.

If he rejects the offer and pursues litigation, we assume a subsistence cash flow of $\$ 6984$ per year (the 1995 per capita CNMI income) for the first five years. The "reject offer" alternative has six possible outcomes after five years: he could be awarded nothing (in which case the subsistence cash flow of $\$ 6984$ a year continues), $\$ 5$ million, or $5 \%, 10 \%, 20 \%$ or $100 \%$ of the after-tax estate ( $\$ 337.5$ million). The probability of each outcome is computed from Figure 1. If he is awarded a non-zero portion of the estate, rather than consuming the entire amount in one year, we again posit a level consumption from year to year (where any amounts not consumed are invested and earn $6 \%$ interest) and a 65 year life span. ${ }^{5}$ For example, there is probability 0.09184 that he will be awarded $5 \%$ of the estate, in which case he will consume $\$ 985,050$ per year in years 6 thru 65 .

With these simplifications, we consider two different instantaneous utility functions: logarithmic and power utility with exponent -1 . Both logarithmic and power utility functions have constant relative risk aversion, a common assumption in modeling individual choice.

\footnotetext{
${ }^{4}$ We make no claim that this consumption behavior is optimal, merely that it is easy to compute and that it has real-world examples: mortgages and state sponsored lotteries. For example, when $\$ 1$ million is won in the California State Lottery, the winner has a choice between payments of $\$ 50,000$ per year for 20 years or a lump-sum payment of about $\$ 500,000$ (the exact figure depends on the price of zero-coupon US treasuries). Real estate mortgages are typically paid in constant amounts per period over 30 years.

As noted in Smith (1998), a complete multi-period consumption optimization problem that allows borrowing and lending is computationally complex, even with simplifying assumptions. The only case with tractable analytics is exponential utility. Our model of consumption does not allow Junior to borrow (and he has nothing to lend) unless and until a settlement is received, at which time borrowing is unnecessary.

${ }^{5}$ If Junior is awarded a non-zero portion of the estate, we assume he does not work and hence does not earn the average per-capita income of $\$ 6984$.
} 
Logarithmic utility is often used in financial models. ${ }^{6}$ On the other hand, Blume and Friend (1975) estimate a power utility with exponent -1 from investment data. ${ }^{7}$

Suppose Junior Larry has logarithmic instantaneous utility for consumption: $u_{i}\left(x_{i}\right)=$ $\log _{10}\left(x_{i}\right)$. The utility of the settlement offer is 65.733 , and the utility of pursuing litigation is 52.211: accepting the settlement offer dominates continuing the litigation (see Table 2). In order to see the enormous impact of the foregone consumption in years 1 through 5 when he pursues litigation, take note of the following fact: in terms of expected discounted logarithmic utility of consumption, Junior Larry is indifferent between pursuing litigation and accepting a lump-sum settlement of $\$ 983,406$, which produces a $\$ 57,034$ payment in each of the 65 years. This is only $5.86 \%$ of the $\$ 972,600$ yearly consumption assured by the actual settlement offer.

Alternatively, suppose Junior Larry has power utility with exponent $-1: u_{i}\left(x_{i}\right)=1-$

$x_{i}^{-1}$. The utility of the settlement offer is 10.97756, and the utility of pursuing litigation is 10.97668. Again, accepting the settlement offer dominates continuing litigation. In this case, Junior Larry is indifferent between pursuing litigation and accepting a lump-sum settlement of $\$ 213,185$, which produces a $\$ 12,364$ payment in each of the 65 years. This is only $1.27 \%$ of the $\$ 972,600$ yearly consumption assured by the actual settlement offer.

Thus, accounting for utility of consumption, for any reasonable estimates of the parameter values, Junior chose the suboptimal alternative.

\section{Embedded Nash Bargaining}

\subsection{Nash Bargaining}

In the introduction to his well known book Risk, Uncertainty, \& Profit (Knight, 1921/1965, p.x), Frank Knight informs us that "careful analysis also emphasizes the fundamental diffi-

\footnotetext{
${ }^{6}$ In his MBA level Finance text, Francis (1991, p. 619) goes so far as to state "The logarithmic utility function is the most logical representation of rational risk-averse economic behavior."

${ }^{7}$ Cochrane (2001, p. 479) suggests the extreme (in sense of decreasing marginal value of money) power utility with exponent near -50 to account for the equity premium puzzle.
} 
culties of the problem and the fatuousness of over-sangiuine expectations." He then asserts that no one mode of analysis is adequate or tolerable for all purposes for all problems. This is our view as well.

The analysis thus far has focused solely on the decisions made by Junior Larry and his attorneys and has ignored any analysis of the decisions made by the estate and its attorneys. Furthermore, the decision analyses of the previous sections lead to the conclusion that Junior made a very bad decision. We wondered whether there was a non-standard approach that could help to account for his choice. In this section we turn attention to a model of the joint decision making of the two parties. There are (at least) two alternative approaches: noncooperative and cooperative game theory. We rely upon a cooperative approach, modifying and applying the Nash bargaining solution. A non-cooperative approach requires specification of the order of moves (offers) and counter-moves, similar to the method in Rubinstein (1982). The Nash bargaining approach, on the other hand, requires only the specification of the set of feasible payoffs and the payoff if an agreement is not reached. While Nash's original approach is axiomatic and does not specify a process by which the solution is reached, Harsanyi (1956) shows that the Nash solution is the unique solution that can be reached via a sequence of counteracting concessions, and Binmore, Rubinstein, and Wolinsky (1986) further develop the relation between Nash's axiomatic approach and a sequential approach.

The Nash bargaining solution is most easily explained via example. There are two bargainers, 1 and 2, who must divide an infinitely divisible pie of size 100. If they agree to a split $\left(x_{1}, x_{2}\right)$ of the pie that is feasible, i.e., $x_{1}+x_{2} \leq 100$, they each receive the agreed upon amount. If they fail to agree, or if the agreed upon amount is infeasible, they get the disagreement payoff $\left(d_{1}, d_{2}\right)$. Arbitrarily set $\left(d_{1}, d_{2}\right)=(52,28)$ : if they cannot agree, bargainer 1 gets 52 and bargainer 2 gets 28 . The specification of the disagreement payoff is a key modeling choice in any application. Nash (1950) posits four axioms that a solution to this problem should obey: (1) the solution should be invariant to linear transformations of the individual payoffs; (2) the solution should not be Pareto dominated, i.e., there should not be a feasible point that earns both players at least as much as the solution payoff and at least one of them strictly more; (3) an (often debated) axiom known as the independence of irrelevant alternatives; and (4) the solution should be symmetric, i.e., it should not depend on the labeling of the players. Nash showed that there is a unique solution 
satisfying these axioms. It is given by the feasible point $\left(u_{1}, u_{2}\right)$ that maximizes the product $\left(u_{1}-d_{1}\right) *\left(u_{2}-d_{2}\right)$ of the distance of the solution to the disagreement point. A simple graph shows that this point evenly divides the excess above the disagreement point. In the example just described, the disagreement point allocates 80 units, leaving 20 to be evenly divided, hence $u_{1}=52+10=62$ and $u_{2}=28+10=38$. Nash bargaining makes no attempt to model the process by which this outcome is obtained.

Risk aversion (or, more properly, decreasing marginal utility for income in the case without risk) is incorporated in the Nash bargaining model by simply letting $u_{i}$ and $d_{i}$ be measured in utility. Assume the first bargainer has exponential utility with risk tolerance $\$ 1,000$ and the second bargainer is risk neutral. The Nash bargaining solution is the pair $\left(x_{1}, 100-x_{1}\right)$ which maximizes $\left[e^{-52 / 1,000}-e^{-x_{1} / 1,000}\right] *\left[\left(100-x_{1}\right)-28\right]$, so $x_{1}=61.97504$. As anticipated, the risk-averse bargainer obtains less than half of the excess. It is easy to show that his share is decreasing in his risk aversion (i.e., increasing in his risk tolerance). ${ }^{8}$ Incorporating non-linear utility on the part of a bargainer is represented by a rescaling of the axis for that bargainer, changing the shape of the feasible set. As long as both bargainers are either risk neutral or risk averse (i.e., have constant or decreasing marginal utility for income), the feasible set is convex. As in the risk neutral case, the Nash solution lies at the intersection of the Pareto frontier and the 45-degree line from the disagreement point.

The Nash bargaining approach (indeed, almost any game theoretic approach) carries some baggage, in addition to the four axioms listed above, that decision analysts may find objectionable. To quote Nash (1950, p. 55) "In general terms, we idealize the bargaining problem by assuming that the individuals are highly rational, that each can accurately compare his desires for various things, that they are equal in bargaining skill, and that each has full knowledge of the tastes and preferences of the other." To which we would add "and has full knowledge of and agrees with the beliefs of the other." Perhaps most objectionable from a decision-theoretic perspective is the convenient fiction of common knowledge of the tastes, preferences, and beliefs of both parties. [For a critical subjectivist view of these assumptions, see Kadane and Larkey (1982).] The literature that has grown from Nash's

\footnotetext{
${ }^{8}$ More generally, if both parties to the negotiation are risk averse, then an increase in the risk aversion of the first party results in the first party receiving a smaller share of a riskless surplus: see Roth and Rothblum (1982).
} 
original paper is enormous: each of the assumptions has been relaxed in one form or other. Rather than adopting a solution that is a perturbation of the original, we proceed with Nash's bargaining solution, fully acknowledging the questionable nature of some of the assumptions, but leaving to future work their relaxation. ${ }^{9}$

\subsection{The Embedding Procedure}

Suppose that in the simple bargaining example given above, that rather than a disagreement payoff that earns $(52,28)$ for sure, disagreement leads to a chance event with expected payoff $(52,28)$. The chance event may itself be followed by a Nash bargaining game. For example, suppose disagreement in the bargaining situation described above, henceforth stage 1, leads to a certain loss of 20 of the available units (i.e., in stage 2 there are only 80 units to be divided). This loss may be generated either through dissipation of the asset or through time discounting. Suppose disagreement also leads to a chance event: with probability 0.2, the entire 80 units are awarded to bargainer 1 (the reason for this type of allocation will be clearer once we detail the Hillblom litigation); and with probability 0.8 , the bargainers enter a second stage Nash bargaining situation with disagreement payoff $(30,20)$. The Nash bargaining solution for the second stage game evenly divides the 30 units not allocated by the disagreement payoff $[80-(30+20)]$, yielding a solution of $(45,35)$.

Our idea is to embed the Nash bargaining games in a decision tree. The 'decisions' have two alternatives: agree or disagree. Disagreement leads to either an immediate disagreement payoff (as in stage 2), or to a chance event (as in stage 1). The payoff to agreement is the Nash bargaining solution. See Figure 2. The tree in Figure 2 is unusual in that the decision nodes represent a joint decision of the two parties: if they both agree, they move along the upper branches; if either disagrees, they move along the lower branches. We suggest that the resulting embedded Nash bargaining game be solved via backward recursion, inducing a subgame-perfect type restriction on the equilibrium. At the end nodes of the tree along

\footnotetext{
${ }^{9}$ For a more decision-analytic approach to game theory, see Nau and McCardle (1990). See Brandenburger (1992) for an analysis of the common knowledge assumptions underlying Nash equilibria. For treatments of the bargaining problem that relax the complete information assumption, see, e.g., Harsanyi and Selten (1972) or Chatterjee and Samuelson (1983).
} 
the lower branches, the payoff to disagreement is the stipulated $(30,20)$, while the payoff to agreement is the Nash bargaining solution of $(45,35)$. Recall that the Nash solution depends on the disagreement payoffs. That is, the payoffs to the "Agree" branch are determined in part by the payoffs on the "Disagree" branch. Given a choice between $(30,20)$ and $(45,35)$, the bargainers would choose to agree. The nature of the Nash bargaining solution necessarily makes both parties prefer the same "Agree" alternative. Taking one step back in the tree, the expected payoff at the chance node is determined by $(0.2)(80,0)+(0.8)(45,35)=(52,28)$. Thus, $(52,28)$ represents the disagreement payoff at the first stage. The agreement payoff at the first stage evenly divides the remaining 20 units, yielding (62,38). Again, agreement is optimal for both parties, and $(62,38)$ is the solution to the embedded Nash bargaining game of Figure 2.

In any risk-neutral Nash bargaining game, the Nash solution lies at the intersection of the Pareto frontier and the 45-degree line from the disagreement point. If the disagreement point were to change in a way that it stayed on that 45-degree line, there would be no change in the Nash solution. This has a somewhat surprising effect in the embedded Nash bargaining model.

Observation 1: The solution to the risk neutral embedded Nash bargaining model is unaffected by whether or not the bargainers agree or disagree in stage 2 . Because the stage 2 Nash solution is on a 45-degree line from the stage 2 disagreement payoff, when modeled at stage 1 , it does not matter which of the two points is used as the disagreement. ${ }^{10}$

Observation 2: The result noted in Observation 1 holds true even with risk aversion, as long as both bargainers have the same attitude towards risk. That is, the solution to the risk averse embedded Nash bargaining game is unaffected by whether or not the parties agree or disagree at stage 2 . Risk aversion merely rescales the axes, and as long as both axes have the same rescaling, the 45-degree line remains unaffected in the sense that any surplus over the disagreement payoff is evenly shared. If the bargainers have different attitudes towards risk, or if only one of the bargainers is risk averse, the result breaks down. In this case, the surplus is not evenly shared, and one bargainer may have an incentive to threaten disagreement at future stages in order to garner a better stage-1 disagreement payoff, and hence a better

\footnotetext{
${ }^{10}$ We thank an astute referee for noticing this result and asking the question.
} 
stage-1 Nash bargaining solution. An example of such a case is described below.

\subsection{Embedded Nash Bargaining and the Hillblom Estate}

To return to the problem at hand, i.e., the division of the Hillblom Estate, we divide the process into three steps: one year for resolution of the Hillblom Law, one year for DNA testing, and three years for litigation. See Figure 2. The tree in Figure 3 is unusual in that the decision nodes represent a joint decision of the two parties. The nature of the Nash bargaining solution necessarily makes both parties prefer the same alternative. The top number at each node represents the value to Junior (in millions) at that point in the process. The lower number in brackets is the value to the Trust (also in millions). We now describe the derivation of those values.

There are several factors leading to the dissipation of the estate: the consumption discount rate exceeds the investment growth rate of the estate, in part because the estate is narrowly and poorly invested; the legal expenses of both parties could be considerable; and the administrative expenses of the trustees of the estate could be considerable. The earlier an agreement is reached, the greater the value of the estate. We assume the estate has an after-estate-tax worth of $\$ 750 *(.45)=\$ 337.5$ million if divided immediately. For simplicity, assume that the estate dissipates at the rate of $10 \%$ per year. If agreement is not reached at the first decision node, there is one year of dissipation as the Hillblom Law progresses, leaving an estate of size $\$ 337.5 *(.9)=\$ 303.75$ million. If agreement is not reached at the second decision node, there is an additional year of dissipation as DNA evidence is tested, leaving an estate of size $\$ 303.75 *(.9)=\$ 273.375$ million. Finally, if agreement is not reached at the final decision node, there are three years of dissipation as the case makes its way through the court system, leaving an estate worth $\$ 273.375 *(.9)^{3}=\$ 199.29$ million. To begin, we assume both parties are risk neutral.

The embedded Nash bargaining tree is "solved" via rolling back in a manner similar to that used for standard decision trees. Disagreement at the ultimate decision node leads to three years of litigation with an expected payoff for Junior from the judgment chance node of $\$ 24.313$ million $(=[.2(0)+.2(.05)+.4(.1)+.16(.2)+.04(1)](199.290))$. The Hillblom Trust retains the remainder, $\$ 174.977$ million. If the parties can agree at the ultimate decision node, 
they will avoid three years of litigation and the concomitant estate dissipation. As noted above, at the ultimate decision node, the estate has an after-tax worth of $\$ 273.375$ million. The Nash bargaining solution at that node evenly divides the potential dissipation loss due to disagreement, (273.375 - 199.290)/2 =37.042, and adds this to Junior's disagreement payoff of 24.313 for a value to Junior of $\$ 61.355$ million. The Trust retains the remainder, $\$ 273.375$ - $\$ 61.355=\$ 212.020$ million. Note that at the ultimate joint decision node, agreement is the preferred alternative for both parties.

Taking one step back in the embedded Nash bargaining tree of Figure 3 details the result of disagreement at the penultimate decision node when the estate has a value of $\$ 303.75$ million. If there is disagreement, Junior gets the just computed payoff of $\$ 61.355$ million if sufficient DNA exists and there is a DNA match. If the DNA does not match, he gets nothing. If there is not sufficient DNA for testing, he gets $\$ 5$ million. This subtree has an expected value for Junior of $\$ 35.359$ million and an expected value for the estate of $\$ 238.016$ million. If the two parties can agree prior to expending effort on DNA search and testing, they can save one year's worth of estate dissipation, or $\$ 30.375$ million. Evenly dividing the dissipation savings and adding it to the disagreement payoffs produces a Nash bargaining payoff of $\$ 50.547$ million for Junior and $\$ 253.203$ million for the Trust at the penultimate decision node. Again, agreement is the preferred alternative for both parties at the penultimate joint decision node.

Finally, moving back one step in the embedded Nash bargaining tree, Figure 3 details the result of disagreement at the first joint decision node. If the Hillblom Law is not enacted, or is enacted but overturned on appeal, Junior receives the just computed $\$ 50.547$ million. If the Hillblom law is enacted and is sustained on appeal, Junior receives $\$ 5$ million. This subtree has an expected value of $\$ 42.348$ million for Junior and $\$ 261.402$ million for the Trust. If the two parties can agree prior to pursuing the enactment and possible contesting of the Hillblom Law, they can save $\$ 33.75$ million by avoiding one year's worth of estate dissipation. Equally dividing the dissipation savings and adding it to Junior's disagreement payoff yields Nash bargaining payoffs of $\$ 59.223$ million to Junior Larry and the remaining $\$ 337.5 \mathrm{~m}-\$ 59.223 \mathrm{~m}=\$ 278.277$ million to the Trust. As at the other joint decision nodes, the agreement alternative is preferred by both parties at the first joint decision node. Thus, our risk-neutral embedded-Nash-bargaining approach suggests that the estate should offer 
$\$ 59.223$ million to Larry and retain $\$ 278.277$ million for the Trust.

As described above, we believe that an assumption of risk aversion for Junior Larry is imperative. For example, suppose Junior Larry has exponential utility with risk tolerance $\$ 200,000$ and the estate is risk neutral. Let Junior Larry be represented by subscript 1 and the estate by subscript 2. The Nash bargaining solution with exponential utility for Junior and risk neutrality for the Trust is the feasible payoff $\left(x_{1}, x_{2}\right)$ which maximizes [(1 $\left.\left.e^{-x_{1} / 200,000}\right)-d_{1}\right] *\left[x_{2}-d_{2}\right]$. Note that Junior Larry's payoff $1-e^{-x / 200,000}$ and disagreement point $d_{1}$ are both measured in exponential utility. Because the Trust is risk neutral, its payoff $x_{2}$ and its disagreement payoff $d_{2}$ are both measured in dollars. That is, the Nash bargaining solution maximizes the product of the differences measured in the utilities of each of the players.

Following the procedure just laid out in the risk neutral case, but substituting exponential utility with risk tolerance $\$ 200,000$ for Junior Larry, i.e., $u(x)=1-e^{-x / 200,000}$, leads to a disagreement expected utility payoff of $0.80(=.2 * u(0)+.2 * u(.05 * 199.29 m)+.4 * u(.1 *$ $199.29 m)+.16 * u(.2 * 199.29 m)+.04 * u(199.29 m))$ which has a certainty equivalent of $\$ 0.322$ million at the ultimate decision node, and a disagreement dollar payoff to the estate of $\$ 174.977$ million. See Figure 4. Below each branch in Figure 4 is a box with three numbers. The top row represents the payoff to Junior: the number on the right is the expected utility of the subtree that follows and the number on the left is the certainty equivalent in millions of dollars. The number in the bottom row is the value in millions to the Trust. The utilityadjusted Nash bargaining payoff at the ultimate decision node is $\$ 1.559$ million for Junior (which has a utility of 0.99959 ) and $\$ 271.816$ million to the Trust. Taking one step back, the disagreement certainty equivalent payoff is $\$ 0.285$ million (which has a utility of 0.75977 ) for Junior and $\$ 271.502$ million for the Trust. Thus, at the penultimate decision node, the utility-adjusted Nash bargaining payoff to Junior is $\$ 1.295$ million (with a utility of 0.99846 ) and $\$ 302.455$ million to the Trust. If agreement is not reached at the first decision node, the certainty equivalent disagreement payoff to Junior is $\$ 1.335$ million (which has a utility of 0.99874 ) and $\$ 301.788$ million to the Trust. Finally, at the first decision node the Nash bargaining payoffs are $\$ 2.359$ million (with a utility of 0.99999 ) for Junior Larry and $\$ 335.141$ million for the Trust. 
As in the standard decision analysis in section 2, the inclusion of risk aversion on the part of Junior Larry has a dramatic effect on the embedded Nash bargaining solution. Without risk aversion, embedded Nash bargaining suggests a payoff to Junior of $\$ 59.223$ million. With exponential utility with a risk tolerance of $\$ 200,000$, the embedded Nash bargaining payoff for Junior falls to only $\$ 2.359$ million, well below the initial settlement offer of $\$ 12.4$ million. See Table 2 for a summary. Junior needs a risk tolerance of almost $\$ 2$ million for the embedded Nash bargaining payoff to dominate the original settlement offer.

Subgame perfection, as induced by the backward recursion of embedded Nash bargaining, has stronger implications than that which most decision analysts are familiar with. Having preferences that are unaffected by backward recursion is one of the axioms underlying expected utility for an individual decision maker. In game theory, however, satisfaction of backward recursion is an additional assumption which restricts the set of possible equilibria. An equilibrium payoff which is eliminated by subgame perfection can be preferred by one or the other of the bargainers.

For example, in the situation depicted in Figure 4, Junior Larry is risk averse and the estate is risk neutral. At the ultimate decision node (indeed at all decision nodes), agreement is the preferred outcome, and the agreement payoffs are used in the rolling back procedure. Because the estate and Junior do not have the same risk attitudes, the losses due to disagreement are not distributed equally. Hence, as a counterexample to the results of Observations 1 and 2 in section 4 regarding invariance of the stage 1 payoffs with regard to disagreement or agreement at future stages, the estate is made better off at the earlier stages if it threatens to disagree at future decision nodes. Subgame perfection disallows non-credible threats of this sort.

\section{Postscript}

\subsection{Risk versus Uncertainty}

In Risk, Uncertainty, \& Profit, Knight (1921/1965) distinguishes between the risks which are known (and have known or subjective distributions) and the unknown risks, which he 
labels uncertainties. The decision trees in Figures 1-3 embody all of the risks to which Junior Larry's payoffs are subject as per our thoughts in 1996. We must pause for a moment and consider the uncertainties which are neither captured in these figures nor are part of our formal analysis. As described in the next section, there were additional events that we could not have foretold.

When considering any investment or financial undertaking, we can always conjure up additional deleterious events and eventualities that, if known, would reverse our decision to go forward with the investment or project. Enumerating such outcomes is not foolish if we continue the dialogue and seek to see which, if any, of these events have some reasonable chance of occurring. More generally, what we should do is a 360 degree scan of the investment landscape to see if we might reasonably imagine some hitherto unforeseen event that we might later say with regret to ourself, "I wish I had known about that; I wish I had considered that possibility in my analysis."

With respect to Junior Larry's decision to reject the settlement offer, the existence of other pretermitted children was closer to a certainty than a mere possibility. After all, Junior Larry's mother was a barmaid, and the reports of Larry Hillblom's penchant for young virgins were legendary and widely reported. How many other children might appear in the courtroom seeking a share of the estate is exceedingly difficult to surmise. Rather than directly modeling the number of legitimate heirs who might appear, we incorporated their existence in the different shares of the estate Junior could win at trial.

Second, we could, without adding undue complexity, model the size of the estate as a random variable. Whereas we did model the inevitable shrinkage with time, other nefarious possibilities, including defalcation and embezzlement, could render this shrinkage more severe. For example, if the litigation proves to be prolonged, some new DHL executive might engage in self-dealing and otherwise drain the coffers of DHL. Similarly, we could have attempted to model unknown risks at DHL which either were uninsured or exceeded its insurance coverage. But we would never have anticipated the appearance of a Saudi Prince with a $\$ 287$ million claim against the estate. In any case, in early 1996 we decided against modeling the size of the estate as a random variable.

Another uncertainty is the perhaps treacherous action of some unscrupulous lawyer who, 
in effect, steals (or attempts to steal) some or all of Junior Larry's payoff. What if Kaelani Kinney (Junior Larry's mother) and Junior have a falling out; she could attempt to gain control of his money, or she could seek a large share of it, purportedly to use for his benefit.

Such a list of uncertainties is as long as one's imagination. But surely at the very least Junior and his lawyers needed to provide for the appearance in court of other wouldbe siblings if not for other additional eventualities. Hindsight enables us to inject such uncertainties into the analysis at this time, but we elected to retain the figures we developed in the early Spring of 1996 (before we knew that the governor would sign Public Law 10-10) to render our quantitative analysis more like what would have been performed by a consultant at the time of Junior Larry's decision to reject the $\$ 12.4$ million offer. It is incumbent upon the analyst to take care not to become enamored of fatuous "over-sanguine expectations." Surprises are less surprising when you anticipate the unanticipated.

\subsection{Follow the Money}

Disentangling the legal wrangling and following the trail of the money is no easy matter. Herein we provide the highlights as reported in different news outlets, some of it contradictory. This much is certain: the Hillblom Law was enacted and signed by the Governor in June 1996. As of the time of this writing (Summer 2003) no appeal of the law by any party had made its way to the CNMI Supreme Court.

At least 7 potential heirs in addition to Junior Larry surfaced across southeast Asia, each with his or her own set of attorneys. There were varying degrees of circumstantial evidence linking the potential heirs to Larry Hillblom; in fact, he had provided for the care of several of them. Regarding DNA, under a court order one of the primary beneficiaries of the Hillblom Trust (the aforementioned UCSF medical center) delivered a mole to the plaintiffs for DNA testing, announced shortly thereafter that there was a mistake (the delivered mole did not actually belong to Larry Hillblom), and then delivered a different mole. The chain of evidence had been broken, and the plaintiffs no longer trusted the mole to be a reliable source of Larry Hillblom's DNA. To overcome this problem, the set of potential heirs used a novel approach: their DNA was tested to determine whether they shared the same father. This testing was the result of a negotiation between four of the plaintiffs. The result of the test for the four 
who negotiated was to remain confidential but could be used to bolster or deny the claims of others. News of the DNA results was leaked. Four of the eight tested positive as siblings: Junior Larry, Jellian Cuartero of the Philippines, Mercedita Feliciano of the Philippines, and Nguyen Be Lory of Vietnam. The DNA matches were eventually confirmed with legally obtained DNA from Larry Hillblom's mother, for which her grandchildren paid her $\$ 1$ million and deeded her title to a villa in France.

Regarding the size of the estate, the initial estimate of $\$ 750$ million was too large. Nearly $\$ 300$ million of the estate was actually owed to Saudi Prince Saud Bin Naif Abdulazzis, the result of a loan negotiated (but never consummated) a decade earlier. At that time, DHL was in a cash crunch, and Larry Hillblom had negotiated a $\$ 30$ million loan from the Prince. Before the loan was consummated, Larry found other lenders on more favorable terms, and he asked the Prince to stand aside. The price for the Prince standing aside was an interest in DHL, which, at the time of Larry's death, was worth $\$ 287$ million. While we could have gone back and added uncertainty over the size of the estate in the decision analysis of Sections 3 and 4, the uncertainty would only have made Junior's chosen alternative look worse.

Apparently, the positive DNA evidence garnered by the heir claimants, even without confirmatory evidence from Larry Hillblom, provided enough impetus for the estate to enter into settlement negotiations with the heir claimants, an event we had not properly accounted for in our modeling (but might have if we had gotten the advice of counsel). To quote from the "Facts" section of a subsequent lawsuit (CNMI Civil Action 95-626):

The final set of heirship settlement negotiations took place in August and September of 1997, ... After a number of hearings to address issues presented by the Settlement Agreement, the Trustees finally submitted their signatures on November 21, 1997, which by its own terms became the 'Execution Date' of the Agreement. Judge Timothy H. Bellas issued his final order approving the Settlement Agreement on December 17, 1997.

The Settlement Agreement was presented to the Court as a 'global' resolution of the numerous claims and issues contained with the heirship litigation. Of particular importance to the Court was the fundamental fairness of the balance that the Agreement had achieved by respecting Larry Hillblom's testamentary 
intentions as expressed by his will, while at the same time providing for a procedure under which only the proven children of the decedent would substantially share in his estate. In addition to the distribution plan and paternity testing protocol, the Settlement Agreement also provides for monthly Interim Payments to Qualified Heir Claimants, reimbursement to counsel for the Trust and Heir Claimants for certain attorneys' fees and litigation costs, active involvement and information sharing by the distributees in regular estate administration, an allocation of the responsibility of the various distributees for taxes which must be paid by the Estate, as well as a comprehensive set of releases and indemnifications by and among the parties. The Settlement Agreement also sets forth goals for the prudent liquidation and distribution of the Estate along with a timetable for obtaining ancillary and guardianship court approvals and dismissals and for the satisfaction of its other obligations.

We were unable to obtain a copy of the Settlement Agreement to determine the exact distribution, and news reports varied, but the Saipan Tribune on March 23, 1999 reported that there was a planned $\$ 50$ million distribution, with $\$ 30$ million divided between the four qualified heir claimants and $\$ 20$ million going to the Trust. The Saipan Tribune also reported on October 13, 1999 that $\$ 200$ million, the remainder of the estate, was to be distributed: each of the four qualified heir claimants was to get $\$ 23$ million and the Trust was to get $\$ 108$ million. These figures indicate that Junior Larry received about $\$ 30.5$ million, but a June 26, 2000 Saipan Tribune article states he received only $\$ 11.3$ million, and a March 20, 2000, Wall Street Journal article states $\$ 50$ million. Prior to the distribution of the assets, Vo Minh Tan of Vietnam, the potential heir who had entered the confidentiality agreement with three of the others, but whose DNA was reported not to match, sued the other heirs for breaching the confidentiality agreement. He eventually received a judgment for $\$ 4.2$ million from the four children's share of the estate. Subtracting Junior Larry's share (\$1.05 million) of the payment to Vo Minh Tan from the aforementioned \$30.5 million leaves Junior Larry with a purported $\$ 29.45$ million, the figure we adopt as his observed payoff.

Remuneration for the attorneys on both sides was substantial. As of March 1999, attorneys for the Trust had received $\$ 12$ million in legal fees. David Lujan and Barry Israel, attorneys for Junior Larry, received $\$ 4$ million in a side deal from the estate in addition 
to their $45 \%$ contingency fee from Junior. The attorneys for the other qualified heirs had contingency fees of 30-40\%. The Bank of Saipan was paid about $\$ 5$ million as Executor. Attorneys for the Trust sued to have the Bank's compensation reduced. The Executor, i.e., the Bank of Saipan, successfully petitioned the Court to oversee the distribution of the assets and to review the fees for the attorneys for the Trust and attorneys for the plaintiffs - in particular those of Lujan and Israel - in an effort to get the fees reduced. ${ }^{11}$ Finally, while Junior Larry's attorneys' share of the original settlement offer is not known, we do know that they received $45 \%$ of the money Junior Larry collected.

It would be interesting to model Junior's decision from his attorneys' point of view. In order to do so, however, we would need to know the attorneys' share, if any, of the original settlement offer (made prior to their retention). The attorneys' decision tree would match that of Junior in structure, but the contingent payoffs could vary by outcome, and these are unreported in the press. Additionally, the attorneys have a legal fiduciary duty to act in Junior's interests, not their own. We have no reason to believe they did not fulfill their fiduciary duties. One possible (and benign) interpretation is that the attorneys, ignorant of the idea and implications of risk aversion, advised Junior Larry from a risk neutral point of view.

When there is a large sum of money up for grabs, as there was in this case, people can and do behave badly - and they frequently take to the courts to press their interests. For example, the Hillblom case was covered in a Dateline NBC segment in November 1996. In June 2000 Myron Farber, the author of a Vanity Fair article on the case and a co-producer of the NBC segment, sued Mr. Lujan, one of Junior's attorneys, for a $\$ 600,000$ bonus fee that had been promised. Mr. Farber had been hired to provide services to validate Junior's claim, including a "secret" DNA test. So much for an independent press.

\footnotetext{
${ }^{11}$ In an unusual twist, the estate owned a $57 \%$ interest in the Bank, and the heirs received a share of that ownership interest as well. Unfortunately, the Bank of Saipan went into bankruptcy in 2001 so the heirs' ownership interests were worthless.
} 


\section{The Bottom Line}

To recap, in early 1996, 12 year old Junior Larry, acting on the advice of his attorneys, rejected a $\$ 50$ million settlement with a net present value of $\$ 12.4$ million. He received $\$ 7.5$ million in April 1999 and an additional \$21.95 million in mid 2000 (net the payment to Vo Minh Tran). Press reports used this as evidence that Junior had made a good decision, not only confusing good outcomes with good decisions, but, from our view, mistaking a bad outcome for a good one. As detailed in the analysis thus far, we believe that ex-ante Junior made a bad decision. The analysis in the next paragraph reveals that we also believe his bad decision led to a bad outcome vis-a-vis the initial settlement offer.

In order to ascertain whether the observed outcome is a bad one, we have to ask: Is Junior better off with the final distribution than if he had taken the original settlement? That is, if he had perfect foresight in 1996 regarding the final payout, would he have preferred the settlement offer over the final payout. There is no doubt that he got a larger sum of money in the final payout, but he had to wait three to four years to get it. Assume level consumption, $6 \%$ interest, and 10\% discounting. As described earlier, these assumptions imply that the original settlement offer would generate $\$ 972,600$ per year of consumption. Employing the $\log _{10}$ utility of consumption model previously introduced, the utility of this originalsettlement-offer consumption stream is 65.73. With the same assumptions, the observed payout provides an annual consumption of $\$ 1,640,925$ in years 4 to 65 but subsistence living (\$6984) in the first three years. The consumption pattern from the observed payout has a utility of 61.74: equivalent to the utility generated by an annual consumption of $\$ 420,973$ in years 1 through 65, just $43.3 \%$ of the settlement amount. That is, with logarithmic utility for consumption, the original settlement offer dominates the observed payout. A similar conclusion holds for power utility with exponent -1 (see Table 2). Not only did he make a bad decision ex-ante, but ex-post he wound up with a bad outcome relative to the initial offer.

The decision analyses of Sections 2 and 3 highlight the folly of Junior Larry's decision: he should have accepted the estate's $\$ 12.4$ million offer. In fact, from either the risk-aversion analysis or the utility of consumption analysis, he should have accepted much less than $\$ 12.4$ million (see Tables 1 and 2). Furthermore, the embedded Nash bargaining with risk aversion 
of Section 4 produces a solution of $\$ 2.359$ million, reinforcing the point that Junior chose badly. 


\section{References}

[1] Abrams, R.A. and U.S. Karmarkar, "Infinite Horizon Investment-Consumption Policies," Management Science, (1979) 25, 1005-1013.

[2] Binmore, K., A. Rubinstein, and A. Wolinsky, "The Nash Bargaining Solution in Economic Modeling," Rand Journal of Economics, (1986) 17, 176-188.

[3] Blume, M.E. and I. Friend, "The Asset Structure of Individual Portfolios and Some Implications for Utility Functions," Journal of Finance, (1975) 30, 585-603.

[4] Brandenburger, A., "Knowledge and Equilbrium in Games," Journal of Economic Perspectives, (1992) 6, 83-101.

[5] Clemen, R.T. and T. Reilly, Making Hard Decisions, (2001) Duxbury/Thompson Learning, Pacific Grove, CA.

[6] Chatterjee, K. and W. Samuelson, "Bargaining under Incomplete Information," Operations Research, (1983) 31, 835-851.

[7] CNMI Public Law 10-10, available at http://cnmilaw.org/htmldl/pl10-10.pdf.

[8] CNMI Civil Action 95-626, available at http://cnmilaw.org/htmldl/A95-0626\%2098-1112.pdf.

[9] Cochrane, J., Asset Pricing, (2001) Princeton University Press, Princeton, NJ.

[10] "Dateline NBC", November 6, 1996.

[11] Dyer, J.S. and R.K. Sarin, "Relative Risk Aversion," Management Science, (1982) 28, $875-886$.

[12] Frank, R., "The Fatherlode," Wall Street Journal, March 20, 2000, pp. A1, A8.

[13] Francis, J.C., Investments: Analysis and Management, fifth edition (2001) McGrawHill, New York, NY.

[14] Harsanyi, J.C., "Approaches to the Bargaining Problem Before and After the Theory of Games," Econometrica, (1956) 24, 144-157. 
[15] Harsanyi, J.C. and R. Selten, "A Generalized Nash Solution for Two Person Bargaining Games with Incomplete Information," Management Science, (1972) 18, P80-P106.

[16] Howard, R.A., "Decision Analysis: Practice and Promise," Management Science, (1988) 34, 679-695.

[17] Hsee, C.K. and E.U. Weber, "Cross-National Differences in Risk Preference and Lay Predictions," Journal of Behavioral Decision Making, (1999) 12, 165-179.

[18] Kadane, J.B. and P.D. Larkey, "Subjective Probability and the Theory of Games," Management Science, (1982) 28, 113-120.

[19] Knight, F.H. Risk, Uncertainty \& Profit, (1921, reprinted 1965) Harper \& Row, New York, N.Y.

[20] Miller, B.L., "Optimal Consumption with a Stochastic Income Stream," Econometrica, (1974) 42, 253-266.

[21] Nash, J., "The Bargaining Game," Econometrica, (1950) 18, 155-162.

[22] Nau, R.N. and K.F. McCardle, "Coherent Behavior in Noncooperative Games," Journal of Economic Theory, (1990) 50, 424-444.

[23] Roth, A.E. and U.G. Rothblum, "Risk Aversion and Nash's Solution for Bargaining Games with Risky Outcomes," Econometrica, (1982) 50, 639-647.

[24] Rubinstein, A., "Perfect Equilibrium in a Bargaining Model," Econometrica, (1982) 50, 97-109.

[25] Smith, J.E., "Evaluating Income Streams: A Decision Analysis Approach," Management Science, (1998) 44, 1690-1708.

[26] Saipan Tribune articles available at http://www.tribune.co.mp/archive.cfm

[27] Waldman, P., "Heir Freight," Wall Street Journal, May 15, 1996.

[28] Weber, E.U. and C.K. Hsee, "Cross-cultural Differences in Risk Perception, but Crosscultural Similarities in Attitudes Towards Perceived Risk," Management Science, (1998) 44, 1205-1217. 